\title{
THE ANNUAL \\ w.
}

\section{BRITISH SCHOOL AT ATHENS}

No. XXIII.

\section{SESSION $1918-1919$}

\author{
PRINTED FOR THE SUBSCRIBERS AND SOLD ON THEIR BEHAIF BY \\ MACMILLAN \& CO, LIMITED \\ LONDON
}

PRICE THIRTY SHILLINGS NET 


\section{THE ANNUA L}

OF THE

\section{BRITISH SCHOOL AT ATHENS}

No. XXIII.

SESSION 1918-1919.

PRINTED FOR THE SUBSCRIBERS AND SOLD ON THEIR BEHALF BY MACMILLAN \& CO., LIMITED

LONDON 


\title{
THE BRITISH SCHOOL AT ATHENS
}

\author{
PATRON.-HIS MAJESTY THE KING.
}

\section{MANAGING COMMITTEE.}

$$
1918-1919 .
$$

Edwin Hanson Freshfield, EsQ, LL.D.

Walter Leaf, EsQ., Litt.D.

George A. Macmillan, EsQ, D, Litt., Chairman.

Trustees.

Professor Percy Gardener, Litt.D. Appointed by the University of Oxford.

Sir John Sandys, Litt. D. Appointed by the University of Cambridge.

Miss Jane E. Harrison D. Litt., LL. D. Appointed by the Hellenic Society.

Miss C. A. Hutton, ex officio as joint Editor of the Anneal.

Professor R. C. Bosanquet, M.A.

PROFESSOR R. M. DAWKINS, M.A.

J. P. Droor, Esq., M.A.

Sir Francis Elliot, G.C.M.G.

Sir Arthur Evans, D. Litt., L.L.D.

Professor E.rnest Gardner, Litt.D.

D. G. Hogarth, Esq., C.M.G., D.Litt.

Elected by the Subscribers.

Professor J. Lynton Myres, M.A.

Sir Cecif. Harcourt-Smith, C.V.O., LL.D.

M. N. TOD, Esq., O.B.E., M.A.

Sir Charles Walston, Litt.D.

L. Whibley, EsQ., M.A.

A. E. ZIMMERN, EsQ., M.A.

V. W. Yorke, Esq., M.A., Hon. Treasurer, Farringdon Works, Shoe Lane, E.C. 4. John. I'enoyre, Esq., C.B.E., M.A., Secretarv, 19, Bloomsbury Square, W.C. I.

DIRECTOR, I918-1919.

A. J. B. W 


\section{TABLE OF CONTENTS.}

War Service of Students of the School, i9r4-igig. . . . viii MNHMHEXAPIN . . . . . . . . . . . XIV

F. W. Hastuck. . . . . . . . . . . xvi

I. Macedonia : - (Plates I.-XIII.)

Ch. Picard. $\quad \S$ r.-Les Recherches archéologiques de l'Armée Française en Macédoine, I916-1919. . I

E. A. Gardner. ) $\$$ 2.-Antiquities found in the British Zone,

S. CASSON. $f$ 1915-1919. . . . . . 10

F. N. Pryce. Note on a Corinthian Pyxis . . . . $4 \mathrm{I}$

F. B. Welch. $\quad$ 3 -Prehistoric Pottery . . . . . . ${ }^{2} 44$

W. Cooksey. $\} \$ 4$ - - Mounds and other ancient Sites in the

A. M. Woodward. $\}$ Region of Salonika . . . . . 5 I

S. Casson. Note . . . . . . . . . 60

F. B. WeLch. $\quad \S 5$ - -Ancient Sites in the Strymon Valley . . 64

M. N. ToD. $\$ 6$.-Inscriptions . . . . . . 67

A. M. Woodward. $\$ 7$--The Byzantine Castle of Avret-Hissar . . 98

2. F. W. G, FoAT. Notes on Doris (Plate XIV.) . . . . Io4

M. N. Tou. Note . . . . . . . . . I Iо

3. S. Casson. Notes on Prehistoric Mounds in the Caucasus and Turkestan . . . . . I I 2

4. A. J. B. Wace. Saint Gerasimos and the English Admiral - . I 8

5. F. B. Welch. The Folk-lore of a Turkish Labour Battalion . 123

6. A. J. B. Wace. A British Officer on Active Service, I 799 .

7. F. W. Hasluck. The Rise of modern Snyrna . . . . I 39

8. F. L. W. Sealy. Lemnos (Plate XV.) . . . . . . 148

9. S. Casson. Herodotus and the Caspian (Plate XVI.) . . I 75

ı. H. J. W. Trlmard. Some Byzantine Musical Manuscripts at Cambridge . . . . . . . . $\quad$ I94

I I. M. N. ToD, The Macedonian Era . . . . . . 206 
Annual Meeting of Subscribers

Letter from the Secretary of State for Foreign Affairs to the Director of the School . . . . . . . . . . . 223

Income and Expenditure, I9r8-1919 . . . . . . . . 225

Donations and Subscriptions, r918-1919. . . . . . . . 227

List of Subscribers . $\quad . \quad+\quad . \quad . \quad . \quad . \quad . \quad . \quad . \quad .23 I$

List of Directors, Honorary Students, Students and Associates . . . ${ }_{2} 3^{6}$

Rules and Regulations of the British School at Athens . . . . 246

Notice to Contributors . . . . . . . . . . . $\quad 2_{50}$

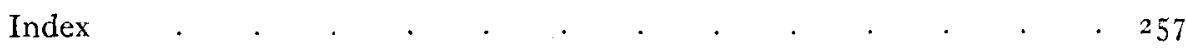




\section{LIST OF PLATES.}

I. Macedonia : Sketch Map showing chief Sites.

II. Macedonia: Pottery. Incised Neolithic Ware. Local sub-Mycenaean Ware from Akbunar.

III. Macedonia: 'Types of prehistoric Vase Handles. Clay Walling. Stone Implements.

IV. Macedonia: Pottery. Pre-Mycenaean painted Ware from Aivatli. Imported Mycenaean Ware. Local Ware.

V. Macedonia: I. Iron-Age Cup from Chauchitza. 2. Kothon from Aivasil. 3. Neolithic Vase with incised Spirals. 4. Corinthian Pyxis.

VI. Macedonia: Bone Needles, Awls, and Polishers.

VII. Macedonia : Bronze Ornaments from Chauchitza. A, Shield Bosses (Classical Period). B, Bracelet and Brooches (Bronze Age). Bell, Ormaments, Bead (Classical Period).

VIII. Macedonia: J. Bronze Helmet. 2. Bronzc Vase. 3. Glass Bottle. 4. Glass Goblet.

IX. Macedonia : Bronze Helmet (Plate VIII. x.) from Greek Cemetery (4th cent. B.c.) on Mikro Bay.

X. Macedonia : t. Marble Bas-relief. 2. Colossal Marble Head of Trajan (?). 2. Marble Statue (ca. $4^{\text {th }}$ cent. s.c.) from Kari Geul.

XI. Macedonia: I. Prehistoric Terracotta Head from the Struma Valley. 2. Prehistoric Mound at Kalamaria.

XII. Macedonia: Tomb of Fourth-Century Type. I. General View of Outer Chamber. 2. Fluted Doric Column. 3. Painted Stucco Decoration of Sima.

XIII. Macedonia: Inscriptions from Laïna (Lete?).

XIV. Notes on Doris : Sketch Map of Part of Doris.

XV. Lemnos: Map of the Island (after the Admiralty Map).

XVI. Herodotus and the Caspian: Sketch Map to illustrate topographical and ethnological Problems. 


\section{LIST OF ILLUSTRATIONS IN THE TEXT}

\section{MaCedonia :- -}

§ 1.-Les Recherches Archéologiques de l'Armée Française, i9i6-19i9.

Fig. I. Sketch Map showing prehistoric Sites on the N.E. and S.E. of the Gulf of Salonika . . . . . . . . . . I

Fig. 2. Sketch Map of the District round Monastir . . . . 3

$\$$ 2.-ANTIQUiTIES FOUND IN THE BRITISH ZONE.

Fig. I. Ground Plan of a built Tomb near Laïna . . . . . . 14

Fig. 2. Tombstone of Q. Julius Alfidius Secundus . . . . 16

Fig. 3. Plan showing Arrangement of Burials at Aivasil . . . $\quad 17$

Fig. 4. Sketch Map of the District . . . . . . . . 18

Figs. 5, 6, 7. Diagrams showing Construction of Grave No. 3 . $\quad$ - 19

Fig. 8. Diagram showing position of the skeleton in Grave No. $3 \quad$. 20

Figs. 9-1 4. Ornaments from Grave No. 3 . . . . . . 21

Figs. 15, 16. Gold Pin and Glass Bead . . . . . . . 22

Fig. I 7. Plan of the Site at Kilometre 70 on the Salonika-Serres Road 34

$$
\text { § 3.-Prehistoric Pottery. }
$$

Fig. I. Prehistoric Pottery from Dikilitash . . . . . . 45

Fig. 2. Id. . . . . . . . . . . . . . 47

Fig. 3. Prehistoric Pottery and Figures from Dikilitash. Pottery from Platanaki and H. Elias . . . . • • . 49

\$ 4.-Mounds and other Ancient Sites in the Region of Salonika.

Fig. I. Sketch Map showing ancient Sites north of Salonika . . 53

Fig. 2. Sketch Map showing ancient Sites between Janesh and the Vardar . . . . . . . . . . . 59

Fig. 3. Sketch Map showing the Area between Salonika and the Struma 62 § 6.-INSCRIPTIONS.

Fig. I. Cippus at Vromeri Skala . . . . . . . 93

Fig. 2. Latin Inscriptions from Fhilippi . . . . . . . 96 
§ 7.-The Byzantine Castle of Avret-Hissar.

PAGE

Fig. I. Avret-Hissar: Sketch Plan of North End and South Gate

I O I NOTES ON DORIS :-

Fig. I. Ruins near Kato Kastelli . . . . . . . . I05

Fig. 2. Plan of the ruined Fort near Kato Kastelli . . . . . 106

Fig. 3. West Wall of Fort at Drymaia . . . . . . . 106

Fig. 4. Wall of ruined Fort near Kato Kastelli . . . . . . $\quad$ 107

Fig. 5. Masonry at Akyphas (?) . . . . . . . . . . 108

Fig. 6. Inscribed Stone from Bralo Valley with Facsimile of the

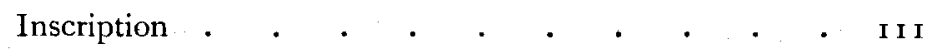

Notes on prehistoric Mounds in the Caucasus and Turkestan.

Fig. I. Sketch Map showing prehistoric Mounds . . . . . I I 3

\section{LEMNOS :-}

Fig. I. Polygonal Wall at Kastro . . . . . . . . $\quad$ I60

Fig. 2. View from the Castle of Kastro, looking North . . . . I60

Fig. 3. Palaeo Pretorio . . . . . . . . . . ${ }_{1} 62$

Fig. 4. Hills containing the Lemnian Earth Pit from the S.E. . . 164

Fig. 5. The Lemnian Earth Pit . . . . . . . . 164

Fig. 6. Perennial Spring (Phthelidia) near the Lemnian Earth Pit . 165

Fig. 7. Kastro Vouni . . . . . . . . . . . . ${ }^{167}$

Fig. 8. View from Kastro Vouni looking N.E. . . . . . . $\quad{ }^{16} 67$

Fig. 9. Underground Building at Kastro Vouni . . . . . 167

Fig. 1o. Fountain at Komi . . . . . . . . . . 168

Fig. I I. Ruins at H. Sophia . . . . . . . . . . . . I69

Fig. I2. Rock Graves at Kaminia . . . . . . . . 170

Fig. I3. Marble Statuette of Kybele . . . . . . . . $\quad$ I 72

Herodotus and the Caspian :-

Fig. I. Hills on the Caspian Shore near Baku, showing the Plain originally covered by the Sea . . . . . . I 80

Fig. 2. Tatar Hut Type in the Mugan Steppe . . . . . 189

Fig. 3. Tatar Huts in the Mugan Steppe between Tiflis and Baku. , ryo

Fig. 4. Horsemen in the Desert (near Merv) east of the Caspian . 191 